\title{
Somaclonal variation on in vitro callus culture potato cultivars
}

\author{
Patricia N. Bordallo ${ }^{1}$; Derly H. Silva ${ }^{2}$; José Maria² ${ }^{2}$ Cosme D. Cruz ${ }^{3}$; Elizabeth P. Fontes ${ }^{4}$ \\ ${ }^{1}$ Plant Transformation Facility, Department of Agronomy, Iowa State University, Ames, IA, 50011-1010, USA; ${ }^{2}$ Depto. Fitotecnia, UFV, \\ 36570-000 Viçosa-MG; ${ }^{3}$ Depto. Biologia Geral, UFV; ${ }^{4}$ BIOAGRO, UFV; E-mail: bordallo@iastate.edu
}

\begin{abstract}
Synthetic seeds can be an alternative for those species in which botanical seeds are not viable. One of the major problems of in vitro plant cultivation is the high level of somaclonal variation. The most common factors affecting somaclonal variation are genotype, explant source, in vitro period and cultivation conditions in which the culture is established. In this work, calli were induced using leaf and stem explants of the commercial potato cultivars Achat, Baraka, Baronesa, Bintje, and Contenda in MS culture media supplemented with 1.65 $\mathrm{mM}$ of picloram and $11.5 \mathrm{mM}$ of 2,4-D. Seventy and 90 days after induction, DNA samples of 40 calli were compared concerning the effects of the two explant (leaf and stem) and two growth regulator sources on five potatoes cultivars. A total of 20 arbitrary sequence primers were evaluated. The RAPD pattern generated by these primers suggested a high percentage of polymorphic fragments among the five genotypes, indicating a high level of genetic variation among cultivars. Cultivar Baronesa showed the highest number of polymorphic fragments for all treatments. The cultivar Contenda showed the smallest somaclonal variation, for most of the treatments, except for the treatment which consisted of stem explants, picloram $(1.65 \mathrm{mM})$ application, and a 70-day period of callus formation. 'Contenda' is, therefore, the most suitable cultivar for synthetic seed production.
\end{abstract}

Keywords: Solanum tuberosum L., synthetic seed, genetic variation, 2,4-dichloro phenoxyacetic acid (2,4-D), picloram.

\section{RESUMO}

\author{
Variação somaclonal in vitro em cultura de calos de cultivares \\ de batata
}

A produção de sementes sintéticas pode ser uma altenativa para culturas, cuja produção de sementes botânicas não é viável. Um dos principais problemas do cultivo de planta in vitro é o alto nível de variação somaclonal resultante. Os fatores mais comuns que afetam a variação somaclonal são genótipo, fonte de explante e duração e condições de cultivo. Neste trabalho, calos foram induzidos utilizando explantes de folha e caule das cultivares comerciais de batata Achat, Baraka, Baronesa, Bintje e Contenda em meio de cultura MS, suplementado com $1.65 \mu \mathrm{M}$ de picloram ou $11.5 \mu \mathrm{M}$ de 2,4-D. Após 70 e 90 dias de indução, amostras de DNA de 40 calos foram analisadas por meio de RAPD, em um estudo comparativo entre os efeitos das duas fontes de explante e os dois reguladores de crescimento nas 5 cultivares. Para este propósito, 20 primers de seqüência arbitrária foram testados. No padrão RAPD gerado por estes primers observou-se alta porcentagem de fragmentos polimóficos entre os 5 genótipos, indicando alto nível de variação genética entre as cultivares. A cultivar Baronesa apresentou o mais alto número de fragmentos polimórficos para os tratamentos. A cultivar Contenda apresentou a menor variação somaclonal genética entre os genótipos e tratamentos utilizados, exceto para o tratamento que consistiu de caule como explante, uso de picloram $(1.65 \mathrm{mM})$ e 70 dias para formação de calos. Portanto, 'Contenda' é a cultivar mais adequada para a produção de sementes sintéticas.

Palavras-chave: Solanum tuberosum L., semente sintética, variação genética, ácido 2,4-dicloro fenoxiacético (2,4-D), picloram.

\section{(Recebido para publicação em 26 de maio de 2003 e aceito em 20 de março de 2004)}

$\mathrm{C}$ ultivated potato (Solanum tuberosum L.) is one of the most important vegetable crop of Brazil and the world's fourth most important crop (Solomon-Blackbourn \& Barker, 2001). In 2002, Brazil produced 3,126,411 t of potato with an average yield of $19,4 \mathrm{~kg} /$ ha (IBGE, 2002).

Potato is a tetraploid species and the use of its botanical seeds in commercial cultivation is precluded by low germinability and large variability in the segregant generations (Gardner \& Snustad, 1986). Synthetic seed is one of the alternatives to solve this problem. The original definition of synthetic seeds, "a single encapsulated somatic embryo", was given by Murashige (1978). In this concept, the synthetic seed is a clonal product that can be handled and used as a real seed for transport, storage and ex vitro as well as in vitro planting. Currently, the most accepted definition of synthetic seed is that of Aitken-Christe et al. (1994): "artificially encapsulated somatic embryos, sprouts and other tissues that can be used for in vitro or ex vitro plantings". This definition extends the concept of synthetic seeds to all types of plant propagules, as structures that can be used similarly to botanical seeds. (Standardi \& Piccioni, 1998).

Somatic embryogenesis produces somatic embryos and can be used for the production of synthetic seeds. However, somaclonal variation may be associated with somatic embryogenesis.
Somaclonal variation, a common phenomenon in plant cell cultures, includes all types of variations among plants or cells and derives from all kinds of tissue cultures (Skirvin et al., 1993). Somaclonal variation is also called tissue or culture-induced variation. (Kaeppler, et al., 2000). Because the goal of synthetic seed production is to obtain clonal identity, controlling the somaclonal variation is a challenge (Amirato, 1991).

Many causes have been identified or proposed for each type of variation; these, however, may vary from species to species and determining the genetic nature of the observed variation is difficult (Maraschin et al., 2002). These variation causes include: changes in the 
structure and/or chromosome number, noticeable point mutations, changes in the expression of a gene as a result of structural changes in the chromosome (heterochromatin and effects of position) or activation of transposable elements, chromatin loss, DNA amplification, somatic crossing over, somatic reduction and structural changes in the cytoplasmatic organelle DNA (Rao et al., 1992; Kaeppler, et al., 2000). Evans \& Sharp (1988) reported four critical variables for somaclonal variation: genotype, explant origin, cultivation period and the cultural condition in which the culture is made.

Plant genotype may have important effects on somaclone regeneration and frequency. These effects are very evident on potatoes: differences are observed in the number of regenerated plants of distinct cultivars grown under identical conditions (Gunn \& Shepard, 1981). It is possible to identify cultivars prone to somaclonal variation, which suggests the involvement of a genetic component on the susceptibility to somaclonal variation (Karp \& Bright, 1985).

Explant source is considered the most frequent critical variable for somaclonal variation. Since explants may present dissimilar regeneration rates, selection procedures can differ among different explants types. Plants regenerated from chrysanthemum petal epidermis-induced calli showed greater somaclonal variation than those from apex-induced calli (De Jong \& Custers, 1986).

The correlation between the culture time-length and the accumulation of chromosome variations was first documented in Daucus carota (Smith \& Street, 1974). Also, Chaturvedi et al. (2001) reported a shift in the morphogenetic pattern of differentiation from shoot bud to embryoid regeneration during the long-term culture of callus of Citrus grandis. Hirochika et al. (1996) reported an increase in the copy number of transposon Tos 17 in rice, when submitted to long periods of incubation.

Addition of growth regulators to culture medium is known to have influence on the frequency of the karyotype alterations in cell cultures. Frequently, the auxin 2.4-D (2.4-Dichloro-phenoxyacetic Acid) is considered to be responsible for the chromosome variation (Singh et al., 1975). Using 2,4-D to substitute ANA (naphtalenoacetic acid) in potato culture medium increases the frequency of abnormal plants (Shepard, 1981). Increasing amounts of 2,4-D enhances methylation levels in carrot cultures (Kaeppler et al., 2000).

Many strategies can be used to evaluate plant genetic structure from in vitro derived plant clones, but most of them have limitations. Karyology analysis cannot reveal alteration in specific genes or in small chromosome arrangements. Isoenzyme markers provide an appropriate method to detect genetic changes. However, these markers are susceptible to ontogenetic variation and are limited in number, and only DNA segments coding for soluble proteins can be sampled. RFLP (Restriction Fragment Length Polymorphism) markers are reliable for sampling various genome regions and are potentially unlimited in number. However, this technique is slow, expensive, and requires large quantities of tissue.

RAPD (Random Amplified Polymorphic DNA) analysis using PCR in association with short primers of arbitrary sequence has been demonstrated to be sensitive in detecting variation among individuals (Xena de Enrech, 2000). The advantages of this technique are: a) a large number of samples can be quickly and economically analyzed using only micro-quantities of material; $b$ ) the DNA amplicons are independent from the ontogenetic expression; and c) many genomic regions can be sampled with a potentially unlimited number of markers (Isabel et al., 1993).

This work had two objectives: 1) identify the method that produces the larger quantity of somaclones with less somaclonal variation for the cultivars analysed, and 2) determine which Solanum tuberosum L. cultivar is the most adequate for synthetic seed production.

\section{MATERIAL AND METHODS}

\section{Potato cultivars and experimental treatments}

The plant material consisted of five in vitro potato commercial cultivars
(Solanum tuberosum L.) Achat, Baraka, Baronesa, Bintje and Contenda obtained from Embrapa Hortaliças. Nodal segments with at least 2 buds were used as plant propagules in MS medium (Murashige \& Skoog, 1962) supplemented with agarose 3\%, 0.6 $\mathrm{mmol} / \mathrm{L}$ myo-inositol, $83.3 \mu \mathrm{mol} / \mathrm{L}$ cisteine, $26.6 \mu \mathrm{mol} / \mathrm{L}$ glycine, $2.9 \mu \mathrm{mol} /$ $\mathrm{L}$ thiamine- $\mathrm{HCl}, 2.4 \mu \mathrm{mol} / \mathrm{L}$ pyridoxine, $4.0 \mu \mathrm{mol} / \mathrm{L}$ nicotinic acid, $1.4 \mu \mathrm{mol} / \mathrm{L}$ giberelic acid, and $\mathrm{pH}$ adjuted to 5.7 (Buso et al, 1989). Plantlets were kept under 1000 lux with 16 hours photoperiod at $25^{\circ} \mathrm{C}$. The medium described previously was supplemented with picloram $(1.65 \mu \mathrm{mol} / \mathrm{L})$ or $2,4-\mathrm{D}$ $(11.5 \mu \mathrm{mol} / \mathrm{L})$ and used to induce callus formation under dark conditions at $25^{\circ} \mathrm{C}$. Stem and leaf explant sizes were approximately $1 \mathrm{~cm}$ long and $1 \mathrm{~cm}^{2}$, respectively.

Each of the five cultivars was submitted to eight treatments of callus induction. In terms of callus cultivation, treatments 1 to 4 , and 5 to 8 consisted of 70 and 90 days culture time length, respectively. Considering traits explant and growth regulators, treatments were set as follows: 1 and 5, leaf and 2,4-D (11.5 $\mu \mathrm{mol} / \mathrm{L}) ; 2$ and 6 , stem and 2,4-D (11.5 $\mu \mathrm{mol} / \mathrm{L}) ; 3$ and 7 , leaf and picloram (1.65 $\mu \mathrm{mol} / \mathrm{L}) ; 4$ and 8 , stem and picloram (1.65 $\mu \mathrm{mol} / \mathrm{L})$, in that order. The control source plant is represented by treatment 9 .

Isolating the genomic DNA for RAPD analysis and amplification reactions

Genomic DNA of plants and calli were extracted using a modified protocol from Doyle \& Doyle (1990). The RAPD analyses were carried out as described by Williams et al. (1990). Twenty primers (Operon Technologies Inc., Alameda, CA, USA), that were selected due to their efficiency for DNA amplification of all cultivars are presented in Table 1.

The amplification reactions were performed in a Perkin-Elmer 9600 thermocycler (Norwalk, CT USA), programmed for 40 cycles of 15 seconds at $94^{\circ} \mathrm{C}, 30$ seconds at $35^{\circ} \mathrm{C}$, and 1 minute at $72^{\circ} \mathrm{C}$. The amplification products were analyzed by electrophoresis in $1.2 \%$ agarose gel and visualized under UV light. 
Table 1. Primers used in RADP analysis. Viçosa, UFV, 1996.

\begin{tabular}{cccc}
\hline Primer code & Sequence $\mathbf{5}^{\prime} \rightarrow \mathbf{3}^{\prime}$ & Primer code & Sequence $\mathbf{5}^{\prime} \rightarrow \mathbf{3}^{\prime}$ \\
\hline OPA-09 & GGGTAACGCC & OPQ-17 & GAAGCCCTTG \\
OPA-10 & GTGATCGCAG & OPR-11 & GTAGCCGTCT \\
OPA-11 & CAATCGCCGT & OPR-12 & ACAGGTGCGT \\
OPB-07 & GGTGACGCAG & OPS-03 & CTACTGCGCT \\
OPB-08 & GTCCACACGG & OPS-05 & TTTGGGGCCT \\
OPC-09 & CTCACCGTCC & OPS-11 & AGTCGGGTGG \\
OPD-01 & ACCGCGAAGG & OPS-13 & GTCGTTCCTG \\
OPD-04 & TCTGGTGAGG & OPS-14 & AAAGGGGTCC \\
OPQ-11 & TCTCCGCAAC & OPT-14 & AATGCCGCAG \\
OPQ-14 & GGACGCTTCA & OPT-17 & CCAACGTCGT \\
\hline
\end{tabular}

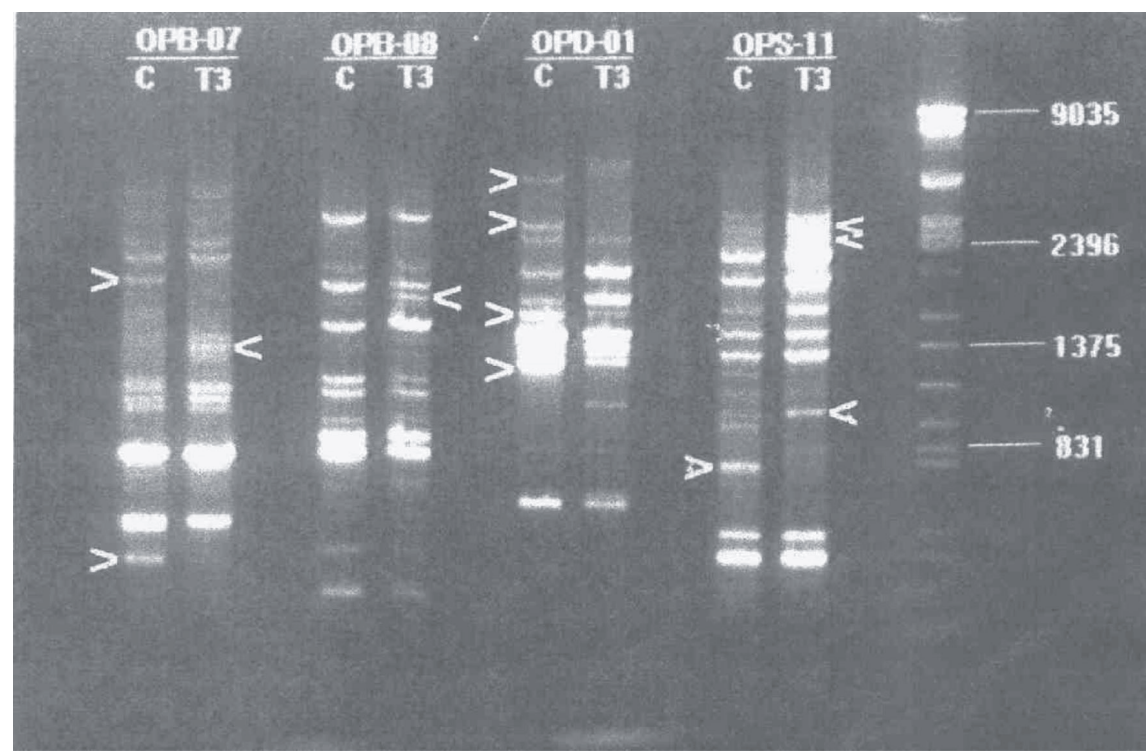

Figure 1. RAPD treatment 3 polymorphism detection for the Contenda cultivar. The genomic DNA of the Contenda cultivar (C-source plant) and the treatment 3 (T3) induced calli were amplified using the primers indicated on the top of the Figure. The analyzed variables in the referred treatment were leaf explant callus, 70 days of callus formation and Picloram as growth regulator. The electrophoretic migration position of the DNA patterns in base pairs is indicated at the right hand side of the picture. The arrows indicate the polymorphic bands. Viçosa, UFV, 1996.

\section{Statistical analysis}

Cluster analysis of individuals within each potato cultivar was performed adopting as measure of dissimilarity the arithmetic complement of the Jaccard index, which is given by: $\mathrm{J}=\mathrm{a} / \mathrm{a}+\mathrm{b}+\mathrm{c}$, where,

$a=1-1$ : number of coincidence of the type "1" and "1";

$b=1-0$ : number of non-coincidence of the type " 1 " and " 0 "; and;

$\mathrm{c}=0-1$ : number of non coincidence of the type " 0 " and " 1 ";

and
$1=$ presence of band; and,

$0=$ lack of band.

The arithmetic complement expressed by $\mathrm{DJ}$ is given by $\mathrm{DJ}=1-\mathrm{J}$.

The cluster technique used was based on the method of Tocher (Cruz \& Regazzi, 1997).

\section{RESULTS AND DISCUSSION}

Eighteen out of the 20 primers used in this research presented polymorphic bands in the calli DNA amplification process after the 8 treatments. The number of primers that presented polymorphism to at least one of the treatments for each cultivar was: 5 to Baraka, 4 to Bintje, 14 to Contenda, 7 to Baronesa, and 4 to Achat. The present analysis suggested that the RAPD methodology was efficient in detecting somaclonal variation in potatoes.

The method of Tocher allowed the construction of two clusters for the Baraka cultivar. Cluster A was formed by calli-derived treatments $1,2,3,4,5$, 6,8 and 9 , and the cluster B was formed by the calli from treatment 7 . The method showed that treatment 7 (leaf, picloram and 90 days of callus formation) was the most effective in the induction of somaclonal variation, suggesting an interaction between the explant, the growth regulator, and long periods of cultivation that increased variability. Varying the cluster routine (i.e. Nearest Neighbor Analysis) had no effect on the grouping of treatments for this cultivar, or the other tested cultivars.

Three distinct clusters were obtained for the Bintje cultivar by the method of Tocher: cluster A was formed by calli from treatments 2, 3, 4, 5, 6, 7 and 8; cluster B was formed by the control source plant (treatment 9); and cluster $\mathrm{C}$, by calli from treatment 1 , which also generated the most genetically-distant individuals. Treatment 1 involved picloram, leaf explants, and 70 days of calli formation; it induced more somaclonal variation than the others. An unexpected result occurred in this case because a greater number of polymorphic fragments was expected for the same treatment condition after 90 days of callus formation than after 70 . The premise that prolonged periods of in vitro cultivation result in increased frequency of chromosome aberrations was not supported by the results (Bayliss, 1980; Larkin, 1987; Karp \& Bright, 1985).

Fourteen, out of the 20 primers tested in the Contenda cultivar, showed polymorphic fragments from leafderived calli (treatment 3 - leaf explant, picloram $(1.65 \mathrm{mM})$ and 70 days of callus formation). The cluster formation confirmed this result. This significant effect of the picloram treatment conflicts with reports in literature that describe 
2,4-D as the most efficient growth regulator for promoting somaclonal variation. Figure 1 shows the results of the amplification products of Contenda cultivar leaf-derived calli from treatment 3 by comparing polymorphic fragments with the control plant.

Two clusters were obtained for the Baronesa cultivar. Cluster A contained calli from all the treatments while cluster B contained the control source plant (treatment 9). The RAPD analysis showed that, among the genotypes analyzed, the Baronesa cultivar presented the highest number of polymorphic fragments for all treatments. This shows that susceptibility to somaclonal variation is related to genotype, as described by Roest et al. (1981). They found 43\% variability in one Begonia hiemalis cultivar and only $7 \%$ in another. Likewise, differences in somaclonal variation incidence in three potato cultivars were observed: Russet Burbank cultivar somaclones showed higher variability than those of the Kennebec and Superior cultivars (Rietveld et al., 1993).

The method of Tocher divided the Achat cultivar treatments in two clusters. Calli stemming from treatments 6 and 8 were in cluster B; the others were in cluster A. Results showed the joint effect of time of callus formation and growth regulators on promoting greater somaclonal variation than other treatments. Likewise, Mangolin et al. (2002) found a high genetic variability in callus tissue of Cereus peruvianus maintained with $4 \mathrm{mg} / \mathrm{L} \mathrm{2,4-D} \mathrm{and} 4 \mathrm{mg}$ / L or $8 \mathrm{mg} / \mathrm{L}$ kinetin. Larkin (1987) reported that longer period of in vitro cultivation seemed to increase somaclonal variations, whereas a shorter callus phase should reduce them.

Our results showed that RAPD analysis allows discrimination of the treatments for induction of somaclonal variation. This conclusion is similar to the results obtained by Mangolin et al. (2002) regarding analysis of genetic variation in callus of Ceres peruvianus. Thus, this strategy can be used to evaluate integrity of in vitro propagated genetic material. Because only micro quantities of material are needed and also because the protocol for DNA isolation from calli and leaves is relatively simple, this methodology can be used to evaluate each step of the in vitro culture, until the regenerated plant is obtained.

Except for treatment 3, which consisted of leaf as explant source, picloram ( $1.65 \mathrm{mM})$ and 70 days of callus formation, all treatments using the Contenda cultivar showed the smallest genetic variation among the five tested cultivars for in vitro cultures. Contenda was, therefore, the most appropriate cultivar to be used for the production of synthetic seeds. An alternative would be the Achat cultivar, because the combination of 2,4-D or picloran leaf explant, and periods no longer than 70 days did not present somaclonal variation.

\section{ACKNOWLEDGEMENTS}

The authors would like to thank Marisa Corzanego for critical reading during the preparation of the manuscript. Financial support for this research was provided by CNPq (Conselho Nacional de Desenvolvimento e Tecnologia) and FAPEMIG (Fundação de Amparo a Pesquisa do Estado de Minas Gerais).

\section{LITERATURE CITED}

AITKEN-CHRISTIE, J.; KOZAI, T.; SMITH, M.A.L. Glossary. In AITKEN-CHRISTIE, J.; KOZAI, T.; SMITH, M.A.L. (Eds.) Automation and environmental control in plant tissue culture. Dordrecht: Kluwer, 1994. p. ix-xii.

AMMIRATO, P.V. Embriogênese somática e semente sintética. In: CROCOMO, O.J., SHARP, W.R., MELO, M. (Eds.) Biotecnologia para a produção vegetal. Piracicaba: CEBTEC/FEALQ, 1991. p.189-221.

BAYLISS, M.W. Chromosomal variation in plant tissue culture. International Review of Cytology, v.11a, p.113-143, 1980.

BUSO, J.A.; INOUE, A.K.; REIFSCHENEIDER, F.J.B.; ÁVILA, A.C.; TORRES, A.C.; DUSI, A.N. Produção de batata-semente pré-básica no Centro Nacional de Pesquisa de Hortaliças CNPHEMBRAPA. Avances en la producción de tuberculo-semilla de papa en los paises del cono sur. Oscar A. Hidalgo y Hernán Rincón, eds. Centro Internacional de la Papa (CIP), p.91-92, 1989. CHATURVEDI, H.C.; SINGH, S.K.; SHARMA, A.K.; AGNIHOTRI, S. Citrus tissue culture employing vegetative explants. Indian Journal of Experimental Biology, v.39, n.11, p.1080-1095, 2001.

CRUZ, C.D.; REGAZZI, A.J. Modelos biométricos aplicados ao melhoramento genético. 2. ed. Viçosa: UFV, 1997. 390 p.

DE JONG, J; CUSTERS, J.B.M, Induced changes and flowering of chrysanthemun after irradiation and in vitro culture of pedicels and petals epidermis. Euphytica, v.35, p.137-148, 1986.

DOYLE, J.J.; DOYLE, J.L. Isolation of plant DNA from fresh tissue. Focus, v.12, p.13-15, 1990. EVANS, D.A.; SHARP, W.R. Somaclonal and Gametoclonal Variation. In EVANS, D.A.; SHARP, W.R.; AMMIRATO, P., V. (Eds.) Handbook of Plant Cell Culture. New York: Macmillan Publishing Company, 1988. v.4, p.97132.

GARDNER, E.J.; SNUSTAD, P. Genética. Rio de Janeiro: Guanabara,1986. 497 p.

GUNN, R.E.; SHEPARD, J.F. Regeneration of plants from mesophyll-derived protoplasts of British potato (Solanum tuberosum L.) cultivars. Plant Science Letters, v.22, p.97-101, 1981.

HIROCHIKA, H.; SUGIMOTO, K.; OTSUKI, Y.; TSUGAWA, H.; KANDA, M. Retrotransposons of rice involved in mutations induced by tissue culture. Proceedings of the National Academy of Sciences, v.93, p.7783-7788, 1996.

IBGE. Banco de dados agregados. Sistema IBGE de recuperação automática SIDRA, 2002. Disponível em < http://www.sidra.ibge.gov.br/bda/tabela/protabl1.asp? $\mathrm{z}=$ teo=11>, Acesso em $11 \mathrm{fev}$. 2004.

ISABEL, N.; TREMBLAY, L.; MICHAUD, M; TREMBLAY, F.M.; BOUSQUET, J. RAPDs as an aid to evaluate the genetic integrity of somatic embryogenesis-derived populations of Picea mariana (Mill.) B.S.P. Theoretical and Applied Genetics, v.86: p.81-87, 1993.

KAEPPLER, S.M.; KAEPLLER, H.F.; RHEE, Y. Epigenetic aspects of somaclonal variation in plants. Plant Molecular Biology, v.43, p.179-188, 2000.

KARP,A.; BRIGHT, S.W.J. On the causes and origins of somaclonal variation. Oxford Survey of Plant Molecular and Cell Biology, v.2, p.199-234, 1985.

LARKIN, P.J. Somaclonal variation: history, method and meaning. Iowa State Journal of Research, v.61, p.393-434, 1987.

MANGOLIN, C.A.; OTTOBONI, L.M.M.; MACHADO, M.F.P.S. RAPD markers to evaluate callus tissue of Cereus peruvianus Mill (Cactaceae) maintained in different growth regulator combinations. Biochemical Genetics. v.40, n.9/10, p.351-358, 2002.

MARASCHIN, M.; SUGUI, J.A.; WOOD, K.V.; BONHAM, C.; BUCHI, D.F.; CANTAO, M.P.; CAROBREZ, S.G.; ARAUJO, P.S.; PEIXOTO, M.L.; VERPOORTE, R.; FONTANA, J.D. Somaclonal variation: a morphogenetic and biochemical analysis of Mandevilla velutina cultured cells. Brazilian Journal of Medical and Biological Research, Ribeirão Preto, v.35, p.633643, 2002.

MURASHIGE, T. The impact of tissue culture in agriculture. In: THORPE T.A. (Ed.) Frontiers of plant tissue culture. Calgary: Association for Plant Tissue Culture, 1978. p.15-26.

MURASHIGE, T.; SKOOG, F. A revised medium for rapid growth and bioassay with tobacco tissue cultures. Physiologia Plantarum, v.15, n.3, p.47397, 1962. 
RAO, I.M.; ROCA, W.M.; AYARZA, M.A.; TABARES, E.; GARCIA, R. Somaclonal variation in plant adaptation to acid soil in the tropical forage legume Stylosanthes guianensis. Plant and Soil, v.146, p.21-30, 1992.

RIETVELD, R.C.; BRESSAN, R.A.; HASEGAWA, P.M. Somaclonal variation in tuber disc-derived populations of potato. II. Differential effect of genotype. Theoretical and Applied Genetics, v.87, p.305-313, 1993

ROEST, S.; VAN BERKEL, M.; BOKELMANN, G.S. The use of ANA in vitro adventitious bud technique for mutation breeding of Begonia hiemalis. Euphytica, v.19, p.381-388, 1981.

SHEPARD, J.F. Protoplasts as sources of disease resistance in plants. Annual Review of Phytopathology. v.19, p.145-155, 1981.
SINGH, B.D.; KAO, K.N.; MILLER, R.A. Karyotypic changes and selection pressure in Haplopappus gracilis suspension cultures. Canadian Journal of Genetics and Cytology, v.17, p.109-116, 1975.

SKIRVIN, R.M.; NORTON, M.; MCPHEETERS, K.D. Somaclonal variation: has it proved useful for plant improvement? Acta Horticulturae, v.336, p.333-340, 1993.

SMITH, S.M.; STREET, H.E. The decline of embryogenic potential as callus and suspension cultures of carrot (Daucus carota L.) are serially subcultured. Annals of Botany, v.38, p.233-241, 1974. SOLOMON-BLACKBURN, R.M.; BARKER, H. Breeding virus resistant potatoes (Solanum tuberosum): a review of traditional and molecular approaches. Heredity, v.86, p.17-35, 2001.
STANDARDI, A.; PICCIONI, E. Recent perspectives on synthetic seed technology using nonembryogenic in vitro-derived explants. International Journal of Plant Science, v.159, n.6, p.968-978. 1998.

WILLIAMS, J.G.K.; KUBELIK, A.R.K.; LIVAK, J.; RAFALSKI, J.A.; TINGEY, S.V. DNA polymorphisms amplified by arbitrary primers are useful as genetics markers. Nucleic Acids Research, v.18, p.6531-6535, 1990

XENA DE ENRECH, N. A decade of the RAPD method: possibilities and limitations for plant genetics relationship studies. Acta Cientifica Venezuelana, v.51, n.4, p.197-206, 2000. 